Alice Niemeyer, left, grows vegetables and stonefruit on a family farm between Auburn and Newcastle. Her family makes its living selling their produce at 13 farmers' markets a week during the summer and 6 markets year-round in the Sacramento area.

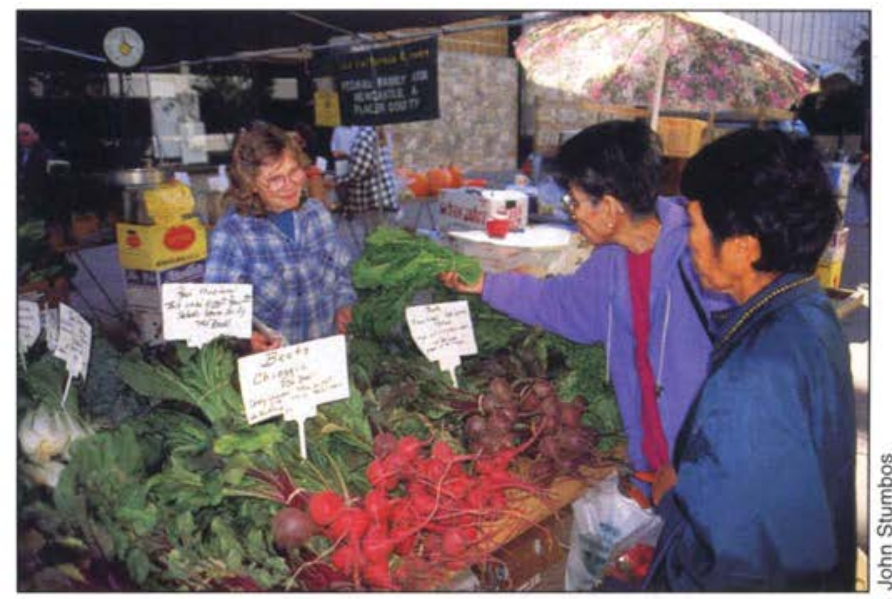

\title{
Farmers' markets offer new business opportunities for farmers
}

\author{
Gail Feenstra $\square \quad$ Christopher Lewis
}

This survey of farmers' market managers shows that farmers' markets offer growers opportunities to expand their businesses by developing new market venues, including community-supported agriculture, institutional food buyers and government food programs; creating value-added products; and making connections with the agritourism industry. The size and location of host communities contribute different kinds of business expansion opportunities. Markets in rural areas offer some of the strongest community support to vendors and link them with the tourist industry. Small-town markets have added the most new vendors in the last 3 years and almost two-thirds of these markets have space, indicating that there is still room for growth. Markets in metropolitan areas may be harder to get into, but they provide the highest gross sales and show the greatest increase in demand for value-added products over the last 3 years. Managers can help growers capitalize on these opportunities through the rapport and connections they develop with community businesses, associations and institutions.
California leads a nationwide trend toward increased consumer-direct farm sales through certified farmers' markets (USDA AMS 1999). Since their authorization in 1977 by the California Legislature, the number of certified farmers' markets in California has risen from 2 to 355 , according to the most recent records of the California Department of Food and Agriculture (CDFA 1999). Certified farmers' markets provide consumers in urban and rural communities with fresh Californiagrown produce, specialty produce and ethnic foods, plants and flowers, meats, dairy, fish, baked goods, handmade crafts and more. For farmers, the markets provide a direct-marketing outlet that avoids the additional costs of middlemen and allows growers to receive retail prices for their products.

In addition to their primary function, farmers' markets foster an environment in which farmers and community members can interact in beneficial and satisfying ways around food. Consumers have the occasion to learn about and support local agriculture, and farmers become more aware of the needs and opportunities in the communities they serve.

It is important that farmers' markets be able to communicate to local and state policy-makers and government officials the range of benefits they offer communities. Although new legislation ( $A B$ 593) recently estab- lished the Certified Farmers' Market Program within the CDFA, regulators continue to need accurate information about the diverse markets in the state to better serve their needs.

It is important that farmers' markets be able to communicate to policymakers the range of benefits they offer to communities. This is even more critical in the current environment, in which state regulations that affect farmers' markets are changing.

Although many benefits of certified farmers' markets have been recognized, their role in providing farmers a fertile entrepreneurial environment in which they can expand their businesses in new ways has remained largely unexplored. To better understand how farmers' markets support local economic development and act as informal "business incubators" for farmers, food-processing and small craft businesses, a 3-year study, funded by USDA's Fund for Rural America, was launched in three states (California, Iowa and New York) in the summer of 1998 . The study aims to explore the ways in which farmers' markets encourage business enterprises, particularly those of small, family farmers, and to identify strategies for farmers and their host communities to support business growth.

The study includes three phases: a telephone survey of 60 farmers' market managers in each state to describe 


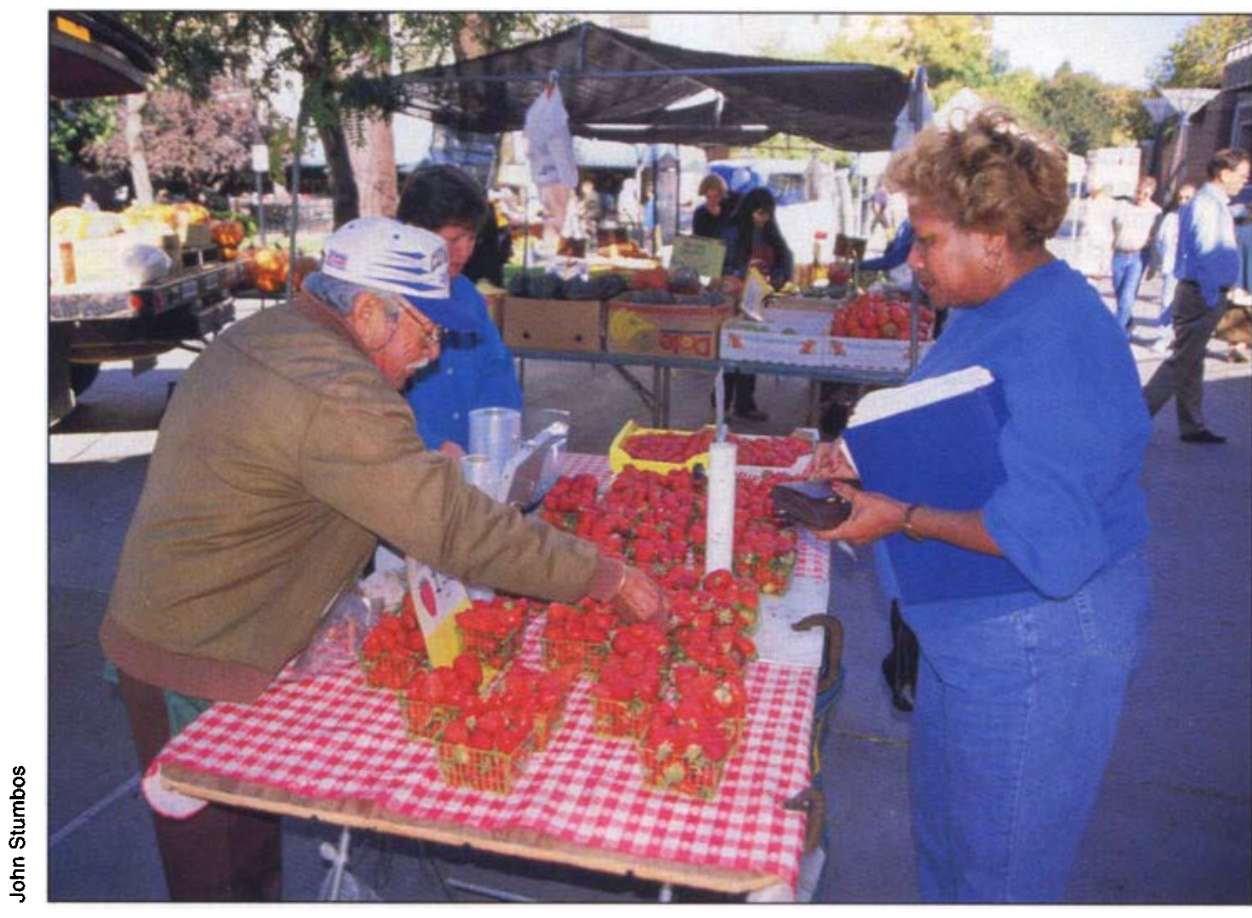

Metropolitan markets, like the Downtown Plaza Certified Farmers Market in Sacramento, are harder to get space in, but they provide growers the highest gross sales.

their markets and identify entrepreneurial activities; a mail survey of approximately 400 vendors from 20 markets in each state to describe entrepreneurial opportunities and challenges from the vendors' perspective; and a set of six case studies of particularly innovative markets or vendors in each state. To date, we have completed phase one - the telephone survey of farmers' market managers.

In this article, we summarize the key findings of the managers' survey. The data presented here provide information about the size and scope of the current farmers' market landscape in California. It also highlights, from the farmers' market managers' perspective, specific opportunities for small farmers that seem to be working well. This data, when added to the vendor survey, will provide a comprehensive picture of trends and opportunities for farmers' markets at the beginning of the new millennium.

\section{Market managers interviewed}

In the summer of 1998, we compiled a list of 335 certified farmers' markets with the help of the state's two largest farmers' market organizations - the California Federation of Certified Farmers' Markets and the Southland Farmers' Market Associa- tion. In this list, we attempted to include only "certified" markets that had been in existence for 3 or more years. California Certified Farmers' Markets are defined in Article 6.5 of the California Administrative Code, which states, "The intent of this article is to facilitate the sale of agricultural products from producers and certified producers within the state directly to consumers while maintaining sufficient regulatory control to ensure that the agricultural products are of acceptable quality and that the selling activities are conducted honestly and fairly."

Certified farmers' markets sell products that are exempt from the standard wholesale pack and grade requirements and thus are subject to less culling. Certification also helps to reduce competition from the resale of wholesale produce and to ensure that only California-grown produce is being sold, in contrast to noncertified farmers' markets and flea markets.

Using 1990 census data, we stratified the list into three categories, based on the population of the host community: rural (population less than 10,000 ), small town (population between 10,000 and 50,000) and metro (population more than 50,000 ). We concluded that $18 \%$ of markets surveyed were in rural communities, $30 \%$ were in small towns and $50 \%$ were in metro areas. This distribution is consistent with a 1993 study of farmers' markets in California (Peck et al. 1993).

We proportionally sampled $60 \mathrm{mar}-$ kets at random from these three categories. Telephone interviews were conducted with the managers of the selected markets, using a standardized interview guide. Interview topics included questions about basic operating characteristics of the market, the managers' rapport with other community businesses, the strategies used to promote the market and farmers' products, and the primary supports and obstacles to entrepreneurial development for farmers.

\section{Market capacity and makeup}

The survey revealed some interesting differences in the operating characteristics, income generation potential and entrepreneurial activities of farmers' markets that take place in small, medium and large communities. Survey responses also suggest that some farmers' markets have created especially innovative entrepreneurial environments that can benefit the farmers who attend them.

The average age of the markets was about 10 years, with small-town markets averaging about 8 years and rural and metro markets averaging about 11 years (table 1). This is consistent with the fact that small-town markets tended to have moved in the last 3 years, more often than rural or metro markets. The small-town markets were also much more likely to have increased the number of vendors who sold at the market (44\%) compared to rural or metro markets $(18 \%$ and $19 \%$, respectively). One-third of small-town markets indicated that they were full, a figure that fell between $27 \%$ (rural) and $42 \%$ (metro). Over $20 \%$ of all managers surveyed said that finding new vendors was one of their greatest challenges.

The survey shows that about $80 \%$ of all vendors at farmers' markets are part-time or full-time farmers, with the remaining $20 \%$ nonfarmers - mostly food businesses (about $10 \%$ ), crafters (about $7 \%$ ) or others (about $3 \%$ ) 
(table 2). These figures show an increase in the percentage of nonfarmers compared to Peck's study (1993), in which an average of $10 \%$ of stalls were rented to nonfarming businesses. The makeup of rural markets differs significantly from small-town and metro markets (table 2). Rural markets tend to have a much greater percentage of part-time farmers compared to markets at small-town and metro sites.

\section{Year-round opportunities}

Sixty percent of the markets surveyed operated year-round, with a much greater percentage of smalltown and metro markets $(61 \%, 74 \%)$ open all year compared to rural markets $(18 \%)$. On any given week during the peak season, an average of about 31 vendors attended each market (table 3). Managers' estimates of the average number of customers per week during peak season also increased with community size from 708 for rural areas, 1,100 for small towns and 2,646 for metropolitan areas. Although these figures are estimates, they fall within the same range as those from a national study by Burns (1996) and a recent study by Lev and Stephenson (1998) that analyzed three farmers' markets in Corvallis, Ore., and Albany, Ore., using more precise measurement methods.

\section{How much do farmers sell?}

Managers estimate market gross sales are approximately $\$ 9,756$ per market per week for all markets, with rural markets grossing about $\$ 3,975$ per week, small-town markets $\$ 7,626$ per week and metro markets about $\$ 12,874$ per week (table 4 ). Using these estimates, we calculate that total weekly gross sales for all markets in the state amount to almost $\$ 3.7 \mathrm{mil}-$ lion, and total annual sales, adjusted for seasonal markets, are about $\$ 140$ million. Per vendor, this comes to about $\$ 400$ per week, less at the rural markets and more at the small-town and metro markets. Customers spend about the same amount, roughly $\$ 10$ per person on average, irrespective of the size of the host community. Again, these figures are consistent with Lev and Stephenson's study, which found that consumers spent from $\$ 11.80$ to $\$ 15.50$ per person per week during peak season. Our figures are somewhat lower because they represent averages over the whole year versus sales from a few peak markets. Our consumer expenditure estimates show, however, that markets in small-town and metro communities are grossing more mainly due to the larger number of customers, not because customers are spending more per person.

\section{Promoting farm business}

The survey revealed some interesting ways in which farmers' market management helps farmers to promote and expand their businesses (table 5). On average, about $40 \%$ of markets offer information to farmers on such topics as how to better market their products, improve signage and build rapport with customers. This kind of help tended to be more common at rural and metro markets, with $45 \%$ offering information, as opposed to smalltown markets, at which only $28 \%$ offered information. On the other hand, almost $100 \%$ of markets offered market promotional activities such as cooking demonstrations, special events and festivals that highlighted farmers' seasonal products. Some managers go so far as to send letters to

TABLE 1. Age and accessibility of farmers' markets

\begin{tabular}{lcccc}
\hline \hline & $\begin{array}{c}\text { Rural } \\
n=11\end{array}$ & $\begin{array}{c}\text { Small town } \\
n=18\end{array}$ & $\begin{array}{c}\text { Metro } \\
n=31\end{array}$ & $\begin{array}{c}\text { Statewide } \\
n=60\end{array}$ \\
\hline Age of market (years) & 11 & 8 & 11 & 10 \\
Markets that run year-round (\%) & 18 & 61 & 74 & 60 \\
Markets with increased no. of vendors (\%) & 18 & 44 & 19 & 27 \\
Full markets (\%) & 27 & 33 & 42 & 37 \\
New location in last 3 years (\%) & 18 & 22 & 19 & 20 \\
\hline
\end{tabular}

\begin{tabular}{|c|c|c|c|c|}
\hline & $\begin{array}{c}\text { Rural } \\
n=11\end{array}$ & $\begin{array}{l}\text { Small town } \\
n=18\end{array}$ & $\begin{array}{l}\text { Metro } \\
n=31\end{array}$ & $\begin{array}{c}\text { Statewide } \\
n=60\end{array}$ \\
\hline & & & (n)......... & \\
\hline Full-time farmers & 47 & 65 & 66 & 62 \\
\hline Part-time farmers & 35 & 17 & 15 & 19 \\
\hline Crafters & 7 & 7 & 6 & 7 \\
\hline \multirow[t]{2}{*}{ Food businesses } & 9 & 11 & 10 & 10 \\
\hline & $\begin{array}{c}\text { Rural } \\
n=11\end{array}$ & $\begin{array}{c}\text { Small town } \\
n=18\end{array}$ & $\begin{array}{c}\text { Metro } \\
n=31\end{array}$ & $\begin{array}{c}\text { Statewide } \\
n=60\end{array}$ \\
\hline & & & & \\
\hline Vendors & 19 & 27 & 38 & 31 \\
\hline Customers* & 708 & 1,100 & 2,646 & 1,818 \\
\hline
\end{tabular}

"Only 13 of 18 small-town market managers and 26 of 31 metro market managers responded to this question, for a total of 50 managers statewide.

\begin{tabular}{|c|c|c|c|c|c|}
\hline & $\begin{array}{c}\text { Rural } \\
n=10\end{array}$ & \multicolumn{2}{|c|}{$\begin{array}{l}\text { Small town } \\
n=8\end{array}$} & $\begin{array}{l}\text { Metro } \\
n=24\end{array}$ & $\begin{array}{c}\text { Statewide } \\
n=42\end{array}$ \\
\hline & \multicolumn{5}{|c|}{, } \\
\hline Per market weekly gross & $3,975.00$ & \multicolumn{2}{|c|}{$7,626.00$} & $12,874.00$ & $9,756.00$ \\
\hline Per vendor weekly gross & 291.00 & \multicolumn{2}{|c|}{316.00} & 474.00 & 398.00 \\
\hline Per customer weekly gross & 11.52 & \multicolumn{2}{|c|}{9.87} & 9.29 & 9.87 \\
\hline & & $\begin{array}{c}\text { Rural } \\
\mathrm{n}=11\end{array}$ & $\begin{array}{l}\text { Small town } \\
n=18\end{array}$ & $\begin{array}{l}\text { Metro } \\
n=25\end{array}$ & $\begin{array}{c}\text { Statewide } \\
\mathrm{n}=54\end{array}$ \\
\hline Info offered to vendors (\%) & & 45 & 28 & 45 & 40 \\
\hline \multicolumn{6}{|c|}{ Organizations offering market assistance } \\
\hline or service (no.) & & 2.0 & 1.7 & 1.6 & 1.7 \\
\hline \multicolumn{6}{|c|}{ Organizations offering entrepreneurial } \\
\hline assistance to vendors (no. & & 0.9 & 0.7 & 1.1 & 0.9 \\
\hline Business expansions/year $\left({ }^{\circ}\right.$ & & 8 & 6 & 7 & 7 \\
\hline Increase in value-added pro & cts (\%) & 36 & 50 & 58 & 52 \\
\hline
\end{tabular}


local restaurants encouraging them to buy direct from market vendors and to promote their markets and vendors' products at other community events and locations.

Farmers' markets help promote business for farmers through the relationships and activities the managers build with other community organizations. For example, in one community, a grocery store sponsors an annual benefit for the local farmers' market and donates the proceeds to the market. In another community, where the market is sponsored by the local Lion's Club, market stall fees contribute to community service projects and organizations such as the teen center and the food bank. These relationships create good will between the markets and the community, contributing to a better business environment for farmers and other market vendors.

It is interesting to note that the rural market managers in our study tended to report slightly more relationships with other community organizations and businesses than did small-town or metro markets (table 5). Metro markets, on the other hand, knew of slightly more organizations in the host communities that could provide specific entrepreneurial assistance to their vendors. Examples of these types of organizations are small business associations, farmer organizations such as the Community Alliance with Family Farmers, UC Cooperative Extension and community colleges.

Market managers are also exploring new community connections that may become important new markets for their growers. For example, several markets have formed relationships with schools or school food services. Not only do the markets offer tours and contact with local growers for school children, they are also finding ways to increase school food purchases from farmers' markets. The Berkeley Unified School District and the Santa Monica School District both offer salad bars with produce purchased from the local farmers' markets. In other communities, managers have made contacts with hospitals and senior citizen centers to explore insti- tutional food purchases from the market. The Farmers' Market Nutrition Program, in which participants in the Women, Infant and Children (WIC) Supplemental food program are given produce vouchers to use at farmers' markets, was mentioned by $42 \%$ of managers in our survey as an important connection with low-income consumers. Studies have shown that WIC participants spend more than their WIC vouchers at the markets and are return shoppers.

\section{Value-added produćts popular}

Fifty-two percent of market managers indicated that they have seen an increase in the production of valueadded products over the last 3 years. Value-added means that a vendor "adds value" to a raw product to make, for example, sun-dried tomatoes, flavored nuts, herbal products or oils. This tended to be more common among markets in metro areas (58\%) as opposed to small town $(50 \%)$ or rural $(36 \%)$. Furthermore, managers estimated that a significant percentage of their vendors have expanded their businesses beyond sales at that particular farmers' market in the last 3 years. The most common type of business expansion was to add another farmers' market. Farmers also expanded their businesses by adding accounts at local stores and restaurants, wholesale accounts and communitysupported agriculture (CSA). Many of these expansions were facilitated by contacts made through certified farmers' markets or by using farmers' markets to test and develop new products. A few expanded by adding farm stands, mail order sales or Internet sales. Although the number of business expansions for farmers is higher in the metro category, when we divide by the total number of vendors, we find that about $6 \%$ to $8 \%$ of vendors per year have expanded their businesses in each category.

\section{Obstacles encountered}

On the other hand, about $43 \%$ of market managers mentioned obstacles to entrepreneurial development - almost half in the metro category, com- pared to $36 \%$ for the rural and $39 \%$ for the small-town categories. The most frequently cited obstacle was inconsistent health department regulations across county lines - in particular, regulations about sampling and selling prepared foods.

Competition with grocery stores is another frequently mentioned obstacle. From the standpoint of market managers who are trying to maintain market viability, grocery stores offer a measure of convenience that farmers' markets cannot often match. This may partially explain why markets in metro regions, where there are usually more shopping options nearby, cite more obstacles to the entrepreneurial success of their markets and vendors than markets in smaller communities.

Market complaints are highest among small-town markets. The most common complaint, by far, is insufficient parking. The fact that small-town markets are younger and less well established in a particular location may explain why parking problems have not been resolved. Some solutions mentioned by managers included scheduling the market on off days, shuttle services and providing driveup tables for customers to pick up their purchases.

Despite complaints, most managers felt that farmers' markets and the farmers who attend them are viewed positively by their host communities. The majority of market managers (78\%) felt that their markets positively affect local businesses, primarily by bringing customers from both inside and outside the community. Several managers gave examples of businesses located in the vicinity of their markets that had expanded their hours to benefit from the increased customer traffic. This revitalization function is commonly used by downtown merchant associations and redevelopment agencies as a rationale for starting a farmers' market.

\section{New expansion opportunities}

Results from this study indicate that certified farmers' markets provide new marketing opportunities for small farmers to expand their businesses. 
Findings show that about $7 \%$ of vendors in each market are expanding their businesses each year. Although most vendors simply add a new market, managers reported that farmers' markets provide important contacts for other marketing venues such as restaurant or retail accounts and CSA startups. Market managers are also helping growers expand their markets by facilitating new relationships with community institutions such as hospitals, senior citizen centers and schools. Farmers at farmers' markets are taking advantage of funding available through government food programs such as the Farmers' Market Nutrition Program and the National School Lunch Program to provide fresh produce to low-income families and children.

In addition to new marketing venues, farmers' markets are providing an important environment for developing and test marketing new products. Our study shows that many of these are value-added products. For example, a farmer can use the farmers' market as a sales outlet for homemade pesto or for a new variety of citrus while working out a production plan, then continue to sell at the market or expand to other retail or wholesale outlets. Customers provide direct feedback, which vendors need as they think about expanding into other venues, crops or product lines.

The market environment provides a healthy forum for managers as well as growers to share marketing and production information with other vendors. They can find out which crops or marketing outlets have worked and which have not and learn about new techniques and specialty crops from other producers. Managers also have the opportunity to pass on information from direct-marketing conferences and organizations that support small farmers and farmers' markets. Our study found that less than half of the managers interviewed offered marketing in-

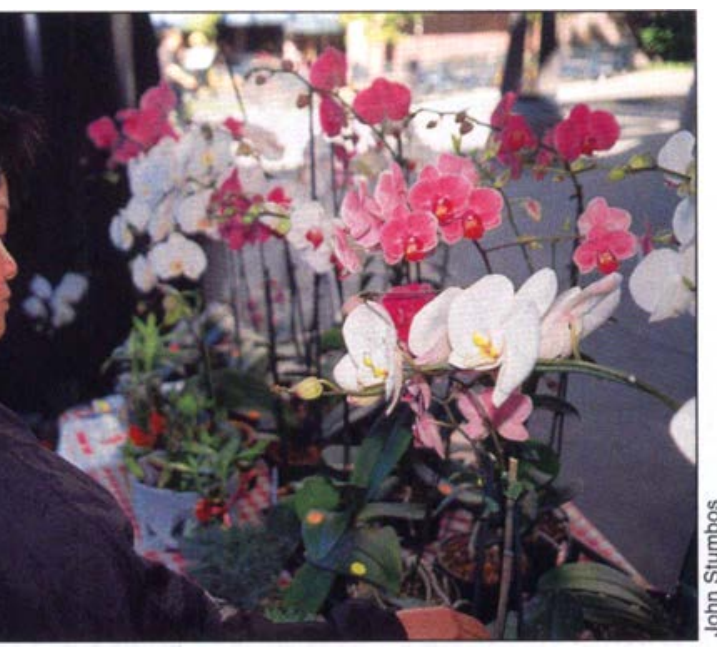

Certified farmers' markets give growers an opportunity to diversify and try specialty crops such as orchids.

formation to vendors. Given the growth in value-added products and new marketing venues, this may be a service that more managers could consider providing.

Our study shows that farmers' markets in different size host communities offer different advantages for vendors. Some of the key characteristics of markets in each category are "indicators" for new farmers considering which markets to attend. Rural markets, such as in Willits and Felton, seem to have some of the strongest community support. In addition to local business and community service organization support, a higher percentage of local residents attend the market compared to small-town or metro markets. Although total gross sales are generally lower at rural markets, they still provide a viable direct-marketing option, and may be more accessible to firsttime growers.

Rural markets also offer opportunities for agritourism and related businesses such as those producing crafts and value-added products and those offering "u-pick" or bed and breakfast services. More than one-third of rural market managers reported significant tourist traffic at their markets. Although only one manager from the remaining two categories also reported a significant tourist customer base, this relatively new marketing venue has potential for growth through all farmers' markets because it provides a valuable direct link between cities and rural areas.
Small-town markets such as in Woodland and Laguna Beach - are younger, are more likely to have moved recently and are the only category that has added a significant number of new vendors. Almost two-thirds of these markets have space for new vendors, indicating that there is still room for growth. They also typically offer a higher volume of sales than rural markets.

Metro markets - such as in Santa Barbara and Riverside - are least likely to have moved recently, and tend to be older markets. They also have the highest percentage of full markets $(42 \%)$. Although metro markets may be harder to get into, they provide the highest gross sales and show the greatest increase in demand for valueadded products over the last 3 years.

This survey of farmers' market managers confirms the growing sentiment in the industry that farmers' markets are contributing entrepreneurial opportunities for growers. In the second phase of the study, we will learn what vendors consider to be the entrepreneurial opportunities to be gained from farmers' markets and the challenges.

G. Feenstra is Food Systems Analyst and C. Lewis is Postgraduate Researcher, UC Sustainable Agriculture Research and Education Program, UC Davis.

\section{References}

Burns AF. 1996. Farmers' Market Survey Report. USDA Agricultural Marketing Service. California Department of Food and Agriculture. 1999. Farmers' Market Listing.

Lev L, Stephenson G. 1998. Analyzing three farmers' markets in Corvallis and Albany, Oregon. Oregon State University Extension Service. http://smallfarms.orst.edu/ analyzing_three_farmers.htm

Peck K, Voss R, Grieshop J, et al. 1993 Popularity has spawned diversity - and rules - at certified farmers' markets. Cal $\mathrm{Ag}$ (47) 2:30-2.

USDA Agricultural Marketing Service. 1999. Features: 1997 Census of Agriculture and Direct Marketing. Farmer Direct Marketing Newsletter April/May 1999. http:// www.ams.usda.gov/directmarketing/ news_04_99.htm\#seven 